\title{
Chapter 12 \\ Role of Community and Government in Irrigation Management in Emerging States: Lessons from Japan, China, and India
}

\author{
Kei Kajisa
}

\subsection{Introduction}

Maintaining well-functioning irrigation systems is a crucial condition for sustainable agricultural development, and many states have implemented different kinds of policies for this aim. In the less-developed countries (LDCs), a conventional issue in this policy arena has been how to mobilize abundant local labor for successful collective management. From the academics, Ostrom's group has made a significant contribution to this end by revealing and synthesizing the conditions for the success, and then in the policy arena in the 1980s and 1990s, a boom of the community participatory approach and the irrigation management transfer (to the local bodies) occurred. The international development society has realized that the use of community mechanism for local resource management is effective for labor surplus countries at an early stage of development.

However, rather than abundant labor, a contemporary issue in the agricultural sector among emerging states, is an increasing labor scarcity. These states have emerged in the global society with their success in labor-intensive industrialization in the areas of textiles, garments, and other light manufacturing. It is because of this success that the agricultural sector has been experiencing labor scarcity. Recent globalization has been accelerating this process by providing rural people with lucrative job opportunities overseas. Facing this trend, an appropriate direction of change in agricultural sector is the substitution of capital for labor. However, as we will explain later, the substitution process entails externalities in a very complicated manner. Therefore, under such a circumstance, the role of the government increases. Understanding the role the government for the achievement of a necessary substitution for sustainable, equitable, and efficient water use is an important contemporary issue of irrigation policies in the emerging states.

\footnotetext{
K. Kajisa (凶)

Aoyama Gakuin University, 4-4-25 Shibuya, Shibuya-Ku, Tokyo, Japan e-mail: kei.kajisa@gmail.com

(C) The Author(s) 2019

K. Otsuka and K. Sugihara (eds.), Paths to the Emerging State in Asia and Africa,

Emerging-Economy State and International Policy Studies,

https://doi.org/10.1007/978-981-13-3131-2_12
} 
Two unique features of the emerging states make the policy issue more complicated than the time when the current DCs had dealt with their increasing labor scarcity. First, groundwater irrigation with private wells and pumps has been becoming rampant. The reduction in the cost of pumps and the excavation of wells have accelerated the exit of farmers from traditional irrigation systems, resulting in a faster increase in labor scarcity in traditional water management. Moreover, the private use of groundwater by individuals entails negative externalities to the neighboring users who share the groundwater aquifer and thus tends to create the problem of "the tragedy of commons." Therefore, an environmental issue comes into the policy arena more seriously than before.

Second, by a recommendation from international organizations or on its own initiatives, some LDCs have introduced volumetric irrigation water pricing with the aim of achieving water savings in their surface irrigation systems. Charging high prices on surface irrigation water may eventually induce farmers to switch to alternative sources for irrigation, which is another form of exit from the traditional irrigation systems. Besides, the implementation of volumetric pricing needs more sophisticated or more capital-intensive irrigation systems as it requires water volume measurement and on-demand water volume control, more or less similar to domestic water systems. Hence, under volumetric pricing system, both labor shortage and the necessity for substituting capital for labor may increase.

Another important point is that we must explicitly incorporate the framework of political economy. Many studies have shown that governments tend to raise agricultural protection in the course of economic development, and the level of protection tends to become excessive. As discussed by Honma in Chapter 10, this is closely related with rent-seeking activities from a shrinking farm sector. Hence, we must explicitly take into account the possibility of protectionism and the government failure as a side effect when the role of the government becomes more important.

In summary, the contemporary issues in irrigation policies of the emerging states are characterized as the achievement of smooth substitution of capital for labor and the achievement of optimal groundwater use under the existence of different kinds of externalities as well as under the pressure of protectionism. The aim of this article is to examine what is the optimal role of the government and what kind of policies are appropriate for the emerging states, using examples of rapidly industrialized or industrializing countries, namely, Japan, China, and India. First, using Japan as a forerunner, we summarize the historical experiences of Japan's irrigation policies and show their pros and cons. Then, using Japan's experience as a benchmark, we evaluate recent policies in China and in India, relying on the case studies of a particular place in each country, namely, Hubei in China and Tamil Nadu in India. Note that Japan's experience does not sufficiently cover the groundwater issue as well as the experiment of volumetric water pricing. We discuss these issues when we analyze the cases of China and India for the sake of obtaining useful lessons for other emerging states. Note, however, that as we rely on the cases of a particular place, we had better refrain from generalizing the lessons excessively.

The rest of the paper is as follows. Section 12.2 shows data on the increasing labor scarcity of our study countries. Section 12.3 explains key concepts such as 
externalities in irrigation systems and government failure and rent-seeking in the political economy framework. Section 12.4 reviews and evaluates irrigation policies in each country. Finally, Sect. 12.5 summarizes the lessons.

\subsection{Changes in Labor Endowment}

Figure 12.1 shows the changes in population and employment by sector from 1950 to 2015 in three countries. Our primary variable as a measure of labor scarcity in the agricultural sector is employment in agriculture. ${ }^{1}$ Since India has data of this variable only in two years, we show also rural population, although this variable includes quite a large number of non-agricultural employment in the rural area, especially in India. Urban population is also shown as a reference.

In Japan, the rural population dropped sharply during its rapid industrialization period (from the 1950s to the 1970s). Even after that period, the exit of labor from the agricultural sector has continued to date as indicated by the employment figure. In China, the agricultural employment figure is available for a relatively longer period. It increased until the early 1990s almost parallel with the trend of urban population, indicating the net labor migration is little. After the take-off of the economy with the economic reform in the early 1990s, the rural employment (and the rural population as well) started decreasing, and this trend has continued till 2015. China's experience after the early 1990s is similar to that of Japan. India's case looks slightly different but is the same in terms of trends. Although the rural population increased continuously, the growth rate looks slower than that of the urban population in the 2000s. Moreover, agricultural employment (indicated by two triangles in the figure) decreased from 2005 to 2010. We conclude that similar to Japan, the two major emerging states, China and India, have started experiencing increasing labor scarcity in the agricultural sector.
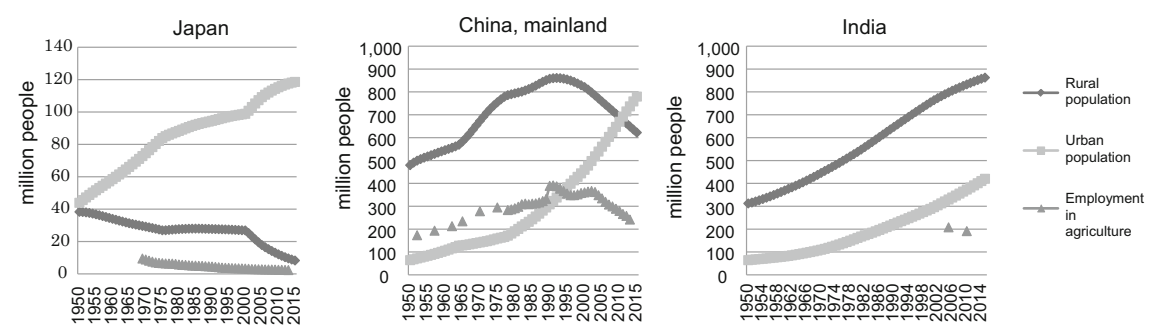

Fig. 12.1 Population and employment by sector in Japan, China, and India from 1950 to 2015. Source FAOSTAT

\footnotetext{
${ }^{1}$ This variable is not perfect in twofold; it measures labor use rather than endowment, and it includes agricultural employment in urban area. Nevertheless, the effects of these problems seem small, and this variable can be used at least as a good measure of trend.
} 


\subsection{Key Concepts}

This section explains four key concepts used in the following case studies: (1) externalities in surface irrigation systems, (2) externalities in non-agricultural sector, (3) externalities in ground water irrigation systems, and (4) government failures in agricultural policies.

Externalities in surface irrigation systems is related with technological indivisibility and collective management of the systems, and they are further divided into two aspects: (a) those related with maintenance of irrigation facilities and (b) those related with allocation of irrigation water. We explain the maintenance aspect first. Once a system is installed to supply water to cover a certain command area, it cannot shrink its supply capacity according to the reduction of the number of users. This is because such systems need to maintain a certain water pressure and a certain water level in order to supply water to the tail-end users. If one user, for example in the midstream, becomes reluctant to fully provide his/her maintenance work or even completely exits from the irrigation system, the remaining users have to shoulder the exiting farmer's maintenance costs to maintain the capacity; this is a negative externality of the exit on the maintenance aspect. Regarding the allocation aspect, the exit of a farmer makes the continuity of irrigation water use along the canal broken. After the exits of some farmers from the irrigation system, the users' plots become segmented from each other, which makes coordination and supervision of allocation among remaining water users more difficult. Although Olson (1965) predicts that the smaller group can make collective action more effectively, such a mechanism may not work in the context of irrigation management if the cost of the former (i.e., coordination difficulty due to scattered plots) is greater than the benefit of the latter (i.e., effective communication in the smaller group). In this manner, the negative externalities are likely to arise on both the maintenance and allocation aspects in the process of farmers' exit from the system, and, thus, the involvement of the government is called for.

The second type of externalities emerge when irrigation water provides nonagricultural benefits, such as drainage services for residences, fire prevention, environmental amenities, and the recharging of groundwater aquifers. Theoretically, these externalities can be internalized by ensuring all beneficiaries are involved in irrigation management. Practically, however, the non-agricultural benefits are so thinly and so widely spread that it is difficult to get all involved. It should be noted that such kinds of externalities also increase with economic development as the numbers of non-agricultural residents increase in rural areas and as groundwater irrigation systems becomes popular.

Because of the existence of these externalities, the private incentives for irrigation investment and management tend to be smaller than the socially optimal level. This problem becomes more serious as industrialization progresses. In the context of surface irrigation management, as labor scarcity increases, the substitution of capital for labor must proceed. However, the necessary investment may not reach to the socially optimal level. The role of government can be observed in supporting capital 
investment in irrigation systems or the modernization of such systems to correct this failure.

Now we move to the case of externalities in groundwater. The over-dissemination of wells and overexploitation of groundwater is commonly observed. This is indeed a typical case of "the tragedy of the commons." The use of groundwater by some individual entails negative externalities for others who share a groundwater aquifer. Without sufficient groundwater recharge, the groundwater will eventually be depleted. Furthermore, in many developing countries, governments use groundwater development as a tool for rural development. Support for such development by the government will make the depletion process more rapid. Regulations or interventions are needed to control for these negative externalities.

Finally, let us discuss government failures. For a clearer understanding of the formation of irrigation policies, it is important to distinguish between two kinds of government failures. The first can occur when asymmetric information exists between the government and the users. The government may fail to provide appropriate support if it cannot precisely estimate the demand for water by the farmers. A possible solution is to get the farmers involved in the project design, which is well-known as a participatory development approach. However, it seems that the use of this solution becomes increasingly difficult for emerging states when support from the government increases and the projects are handled by bureaucrats and technocrats of the irrigation authorities who are usually public servants, rather than local farmers. This may be particularly so when the form of support is financial rather than technical, because an increase in financial support makes the implementation of irrigation projects similar to the provision of pure public goods.

Another type of government failure is related to the political economy. This problem occurs in a way that the government, expecting votes, tends to provide public goods in favor of a particular group of people. As many studies argue, this framework can convincingly explain why agricultural protection rises in many countries when the comparative advantage of the agricultural sector declines and political pressure from the farmers' group increases. In the context of irrigation policies, the government may use support for irrigation as a means of protection, resulting in overinvestment in irrigation facilities, pumps, and wells. Note that agricultural protection can be implemented by many means, such as output price support, input subsidies, income support, and trade regulation. One may argue that support for irrigation is better than price support as the former increases productivity while the latter spoils productivity improvement incentives. Nevertheless, even the irrigation support must be the one which increases labor productivity because the factor getting scarce is labor.

In summary, through experiencing an increase in labor scarcity and/or the development of groundwater irrigation under conditions of rapid industrialization and globalization, the level of different kinds of externalities increases, and thus the need for government interventions increases. Accordingly, the possibility of government failures also increases. Because of such failures, the level of interventions could either be too great or too little with a different combination of policies. The government must achieve an appropriate level of intervention to facilitate the substitution of 
capital for labor as the resource endowment of the economy changes. This is difficult but crucially important for sustainable development. In the following section, we review how Japan, China, and India have dealt with these issues.

\subsection{Case Studies}

\subsubsection{Japan's Irrigation Policies Since the Late 19th Century}

This section provides a historical review of Japan's irrigation policies since the late 19th century. We divide our review into three periods based on the attitude of the government: (1) community-based management (1880s-1910s), (2) increasing financial support by the government (1920s-1950s), and (3) financial takeover and modernization by the government (1960s-2010s).

Community-based management (1880s-1910s) The origin of water management institutions in which we can find the roots of current systems dates back to the 18th century, the mid-Edo period, when the rapid development of new paddy fields increased water demand (Tamaki et al. 1984). Traditionally, irrigation infrastructures were managed by local communities, with some exceptional cases of vast irrigation systems which received supports from local or national authorities (Tamaki and Hatate 1974). After the Meiji Restoration, the government replaced old systems with modern ones, in many respects to "catch up" with the Western world. Exceptionally, however, regarding water institutions, the government approved traditional water rights in the River Act (Kasen-hou) of 1886 and allowed traditional communities to handle the management. In addition, the Irrigation Association Code (Suiri-kumiaizyourei) of 1890 stipulated that irrigation development projects must be financed by private sources (Tamaki et al. 1984). ${ }^{2}$ The local leaders, usually large landlords in the rural area, bore the financial burden, and put their efforts into mobilizing local resources for the development and management of irrigation facilities to improve the social welfare of their local communities. In this regard, we may claim that the government left the role of irrigation development and management to the local communities, and that the local landlords behaved as if they were the local government. The local landlords had incentive to do so not only because they accepted the burden as a local leader and tried to maintain their social status but also because the improvement of land productivity in the entire community could increase the land rent from their tenants. This division of work functioned well when the financial and manpower capacity of the government was limited. Figure 12.2 shows the proportion of financial support for such land improvement projects (mainly irrigation develop-

\footnotetext{
${ }^{2}$ Meanwhile, it was stipulated that projects related to public rivers were publicly financed.
} 


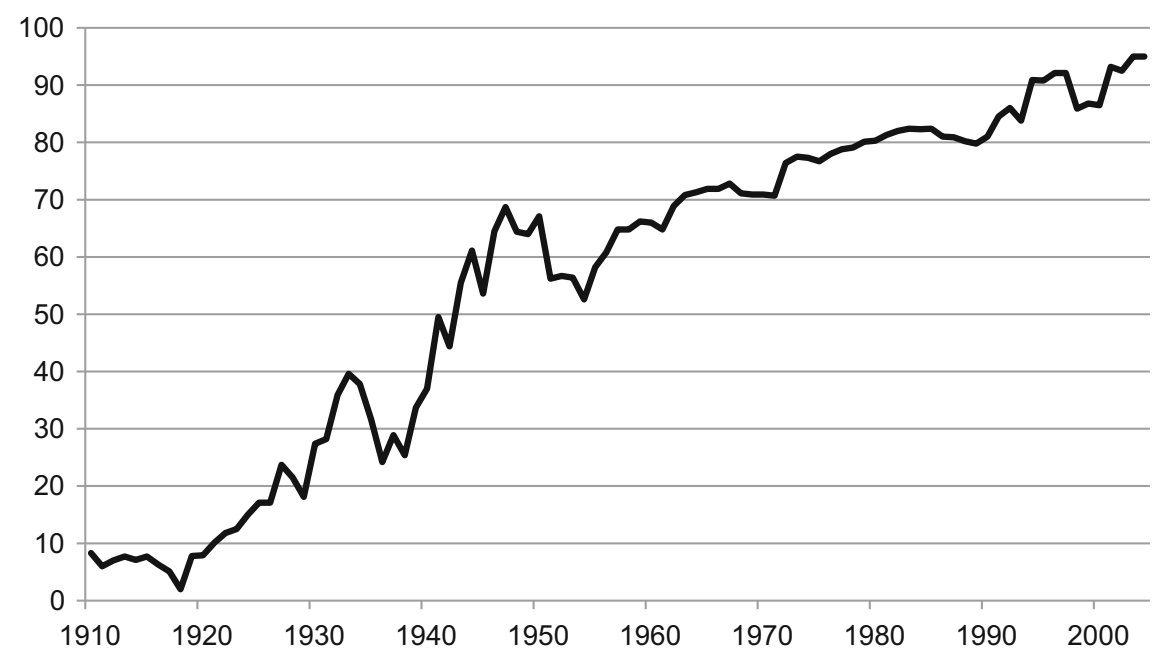

Fig. 12.2 Proportion of financial support for land improvement investment by the central and local government in Japan from 1910 to 2004. Sources National Research Institute of Agricultural Economics (1967) and Ministry of Agriculture, Forestry and Fisheries (various years)

ment) undertaken by the central and local governments from 1910 to $2004 .^{3}$ We can observe that public financial support was rather low in the 1910s.

Financial support by the government (1920s-1950s) There was a turning point in the 1920s regarding the roles of the community vis-a-vis the government. The local landlords lost their interest in investing in the irrigation during this period. The reasons included a low rice price due to increased imports from the colonies, a decline in land rent due to tenancy disputes with tenants, and, above all, an increase in investment returns from emerging modern industrial sectors. Therefore, the agricultural sector became a less attractive investment target for the landlords. Moreover, the transaction costs associated with irrigation development became much greater than the amount that local landlords could shoulder. As the coverage of the irrigation project area became larger, the stakeholder farmers began spreading beyond the locality that local leaders could manage. Therefore, the costs of the coordination of interests, convincing dissenting farmers, and arranging compensation increased in this period.

Meanwhile, a riot caused by the rice shortage in 1918 led the government to realize the importance of achieving an increase in the food supply. However, the government was no longer able to rely on local leaders' initiative, and thus started providing financial support for irrigation development. For example, the guidelines in 1923 (Youhaisui-kansenkairyou-hozyo-youkou) guaranteed 50\% financial support

\footnotetext{
${ }^{3}$ Nakajima (1998) created this figure from 1910 to 1995 . We replicated Fig. 12.2 with the original data from 1910 to 1995 and extended the years using Ministry of Agriculture, Forestry and Fisheries (various years).
} 
from the government for projects greater than 500 ha of irrigation command area. ${ }^{4}$ In summary, as the role of the community (local leaders' financial initiative) declined, the government supplemented it in this period. Figure 12.2 shows that support started increasing in the 1920s. This attitude continued until the 1950s, except during the Second World War, when the government disproportionately mobilized funding for the armament industry. In the 1950s, Japan achieved rice self-sufficiency.

Financial takeover and modernization by the government (1960s-2010s) Japan experienced rapid industrialization and economic growth from the mid-1950s to the mid-1970s. This led to a rapid reduction in the labor endowment in the agricultural sector. This reduction entailed the loss of experienced water tenders, who were knowledgeable about the water control and distribution of their irrigation systems. In parallel, even among those who remained, farming became their side business as their income from non-agricultural works increased. These changes made strict and coordinated irrigation management more difficult among the remaining spatially dispersed farmers, and this difficulty increased further when the experienced water tenders were no longer available. From the relative resource endowment point of view, this means that the need for the substitution of capital for labor (including skilled labor) increased for efficient water use. However, as we explained earlier, this substitution process does not occur automatically as an outcome of the market mechanism. This is because there are externalities rooted in the feature of technological indivisibility and collective management. Moreover, the other type of externality (non-agricultural benefits) arose because the numbers of non-agricultural residents increased in the rural areas adjacent to the urban or industrial zones during the period of rapid industrialization. Because of the increase in the two kinds of externalities in this period, the demand for government intervention increased.

Indeed, the Japanese government strengthened its support for irrigation development in this period. Among many aspects, financial support increased from around $60 \%$ in the 1960 s to $80 \%$ in the 1990 s, and then to more than $90 \%$ in the 2000 s (Fig. 12.2). ${ }^{5}$ The projects in these periods included lining canals with concrete, the replacement of canals with pipelines, the rehabilitation of water intake, and the cleaning of dams and rivers with heavy machines. Automation and the remote control of water flows were also implemented, replacing the roles of the experienced water tenders. These modernization projects substituted capital for labor. In addition, the separation of water supply canals from drainage systems reduced the negative externality from non-agricultural residents.

We can justify the government interventions in this period for two reasons: first, the externalities were corrected by this public support; second, the changes caused by such support were consistent with the changes in the relative resource endowment. These kinds of active interventions were important for smooth economic growth

\footnotetext{
${ }^{4}$ To be precise, the threshold size of the project area was 500 cho, which is almost the same as 500 ha.

${ }^{5}$ There is one exceptional period showing a decrease in the mid-1950s after the achievement of rice self-sufficiency.
} 


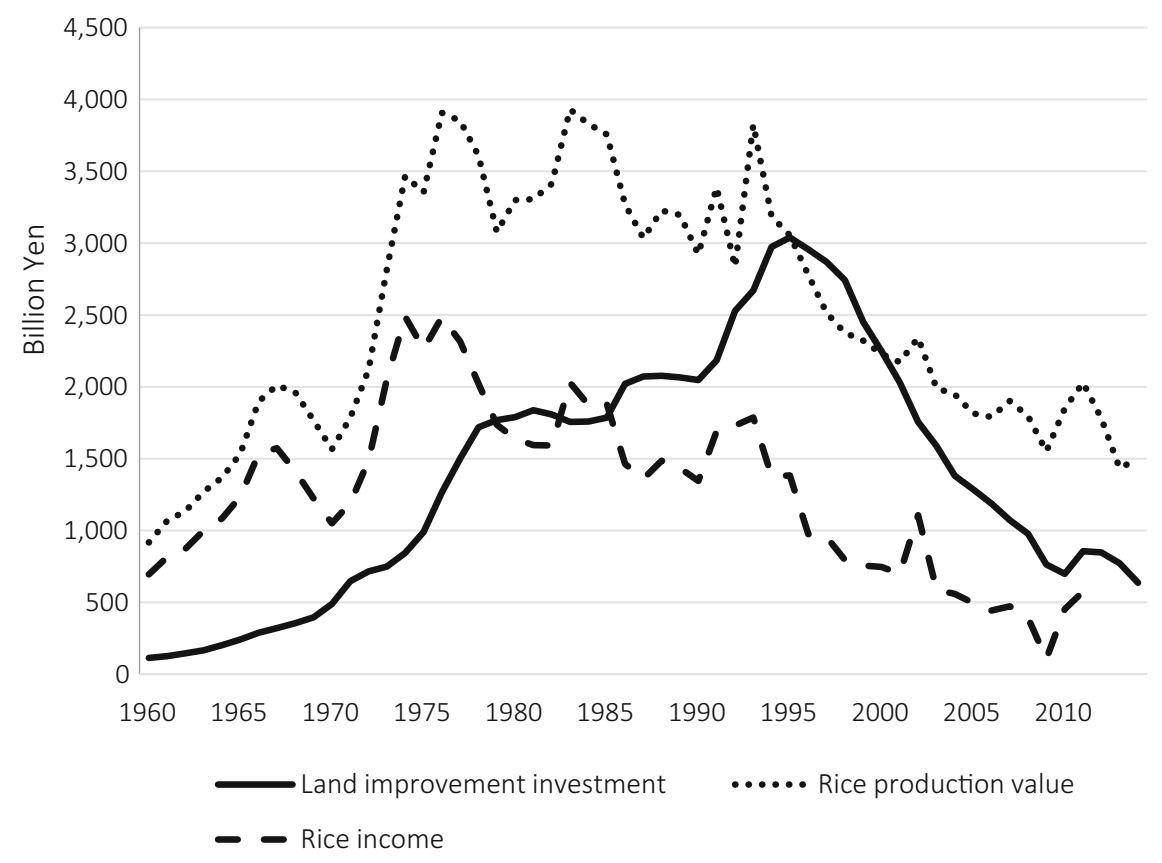

Fig. 12.3 Japan's land improvement investment, rice production value, and rice income from 1960 to 2015. Source Data are from the home page of Ministry of Agriculture, Forestry, and Fisheries (Accessed November 2017). The sources of each series are as follows. Land improvement investment: Nougyou shokuryou kanren no keizai keisan. Rice production value: Seisannnougyou syotoku toukei. Rice income: Nousanbutu seisanhi toukei. Note Rice income is computed as rice income per 10 are times rice cultivated area in 10 acre. Rice cultivated area was taken form Skumotu toukei at the homepage above. The definition of rice income per 10 are is as follows. Income $=$ revenue (total production cost-(imputed family labor cost + imputed capital payment + imputed land rent)). Subsidies are not included in the revenue

because they circumvented the decline in irrigation services and the stagnation of agricultural development.

At the same time, however, it is important to note that increased government interventions raise the risk of government failures. Given the existence of asymmetric information, the reduction in farmers' self-finance and the reduction in farmers' involvement may skew the level of investment toward overinvestment under the pressure of the rent-seeking from the farmers. In order to examine this possibility, we show the time series of the land improvement investment, the value of rice production, and the rice income of Japan from 1960 to 2015 (Fig. 12.3). Although they are rough indicators, we may say that the figure shows the trend of investment and its returns. According to the figure, the investment and returns increased almost parallel until the 1980s. However, after that, the production value and the rice income had declined, while the investment had continued increasing until the early 2000s. 
Major reasons for the decline in the production value from the 1980s to the early 2000 s were the double effects of the drop in the rice procurement price and the reduction in the quantity of rice production. ${ }^{6}$ Even under such an adverse environment, if the cost for production were reduced and thus the profitability improved, the income would not decline this much. However, in reality, the cost was merely reduced, resulting in a sharp decline in rice income as shown in the figure. ${ }^{7}$ It seemed that the investment did not contribute much to the improvement of rice sector profitability in this period. Note that the financial support by the government in the same period increased from 70 to $90 \%$ (Fig. 12.2). Moreover, since the 1970 s the investment target had changed from the modernization of irrigation infrastructure to the improvement of individual farmers' paddy fields, where the new target can be regarded as a private property with much smaller externalities than irrigation infrastructure. In this regard, we may claim that there was overinvestment to the less justifiable target by the government.

After the 2000s, the land improvement investment had declined. Note, however, that the income subsidies to the farmers (data are not shown in the figure), which have less incentive for productivity improvement than the support for land improvement, has been maintained (as of 2017) as a major mean to support the agricultural sector. In summary, Japan's experience teaches us that under increasing labor scarcity in agriculture, it is important to provide public support for the substitution of capital for labor and, at the same time, to introduce an appropriate mechanism that can suppress the tendency for overinvestment under the trend of agricultural protectionism.

\subsubsection{The Case of a Surface Gravity Irrigation Scheme in Hubei, China ${ }^{8}$}

Facing a rapid increase in water demand for urban and industrial use, China aimed to achieve water savings in the agricultural sector, particularly in paddy farming as this was considered the largest water consumer. The major effort to promote

\footnotetext{
${ }^{6}$ We set the comparison period from 1986 to 2003; the beginning year is the year of the record-high price and the ending year is the year the government stopped the rice procurement policy. In this period, the price dropped $26 \%$ from $18,505(y e n / 60 \mathrm{~kg})$ to $13,748(y e n / 60 \mathrm{~kg})$, and the production quantity was reduced $21 \%$ from 11,035 (1000t) to $8,698(1000 t)$ in the same period, resulting in a $38 \%$ reduction in the production value. The reduction of production quantity was mainly due to the enforcement of the policy of reducing rice cultivated area. (Price data are from Shokuryo toukei nenpou, production quantity data are from Seisannnougyou syotoku toukei. Production value data are from Seisannnougyou syotoku toukei. All are taken from the homepage of the Ministry of Agriculture, Forestry and Fisheries)

${ }^{7}$ The average cost of production was reduced by $2 \%$ from 15,312 (yen/60 kg of rice) to 14,963 (yen $/ 60 \mathrm{~kg}$ of rice) from 1986 to 2003 , while the price was reduced by $26 \%$ from 18,505 (yen/60 kg) to $13,748(y e n / 60 \mathrm{~kg})$ in the same period. The total rice income declined by $41 \%$. (Price data are from Shokuryo toukei nenpou, production cost data are from Nousanbutu seisanhi toukei. All are taken from the homepage of the Ministry of Agriculture, Forestry and Fisheries)

${ }^{8}$ This section draws heavily on Kajisa and Dong (2017).
} 
water conservation in the agricultural sector began in the $1990 \mathrm{~s}$, with considerable regional variation in intervention tactics (Lohmar et al. 2007). In 2002, 20 provinces implemented a reform of taxes and fees called fei gai shui. Before the reform, a water fee was included in the land tax, equivalent to area-based pricing (i.e., zero marginal costs for irrigation water). Hence, there was no economic incentive among the users to save water. The reform called for separate water fees and increased independent management for each reservoir. In reaction to this change, many reservoirs began volumetric water pricing and expected this to have a significant impact on farmers' water-saving behaviors. This subsection evaluates the outcomes of this policy, using a survey conducted in an irrigation system (Zhanghe Irrigation System) in Hubei, China, in 2008.

In a surface gravity irrigation system, effective collective action among water users is needed to save water under volumetric pricing. This is because a feasible pricing method measures the volume at a canal's intake, and the total fee is charged to the water user group (WUG) rather than to individual farmers. The total fee is then divided among the WUG members by cultivated area. Therefore, the group has an incentive to save water, while individual farmers within a group may overuse water unless they are closely supervised. Institutional change must play an important role in preventing this free-rider problem within a WUG.

After the reform, institutional changes occurred in the WUG's traditional informal collective management system. These changes can be classified into four categories: (1) no change (or upholding informal management), (2) the formal appointment of water managers, (3) the formation of new smaller groups, each of which was a much smaller sub-set of farmers from neighboring plots only, and (4) individual irrigation using water from private ponds. The changes to (2) and (3) can be regarded as shifts toward water savings through more effective collective management under a manager or within a small group. The change to (4) comprises an exit from the irrigation system, resulting in increasing labor scarcity for management of the surface irrigation system. At the time of the survey, farmers' exit to non-agriculture activities also accelerated the rural labor shortage.

An interesting point is that we observe cases of "(1) no change," even when the price level was high (hence there must have been a large incentive for savings). Figure 12.4 shows the proportion of farmers within each water management institution by the volumetric price level of reservoir water (set at zero for area-based pricing). In the group at the lowest price level, including the case of area-based pricing, the farmers who chose no change account for the largest proportion (46\%). This is a natural outcome because the farmers had little incentive to implement strict management for water savings. As the price goes up moderately, the proportion of manager appointments and that of new smaller group formations increase. When the price goes up further (beyond the 4th price range category), the attractiveness of exiting from reservoir water use increases, and the proportion of individual irrigation then increases. Moreover, the proportion of no change also increases, replacing the other two water-saving institutions (i.e., manager appointment and new smaller groups). The figure generally shows a U-shaped relationship for the volumetric price level with no change. 


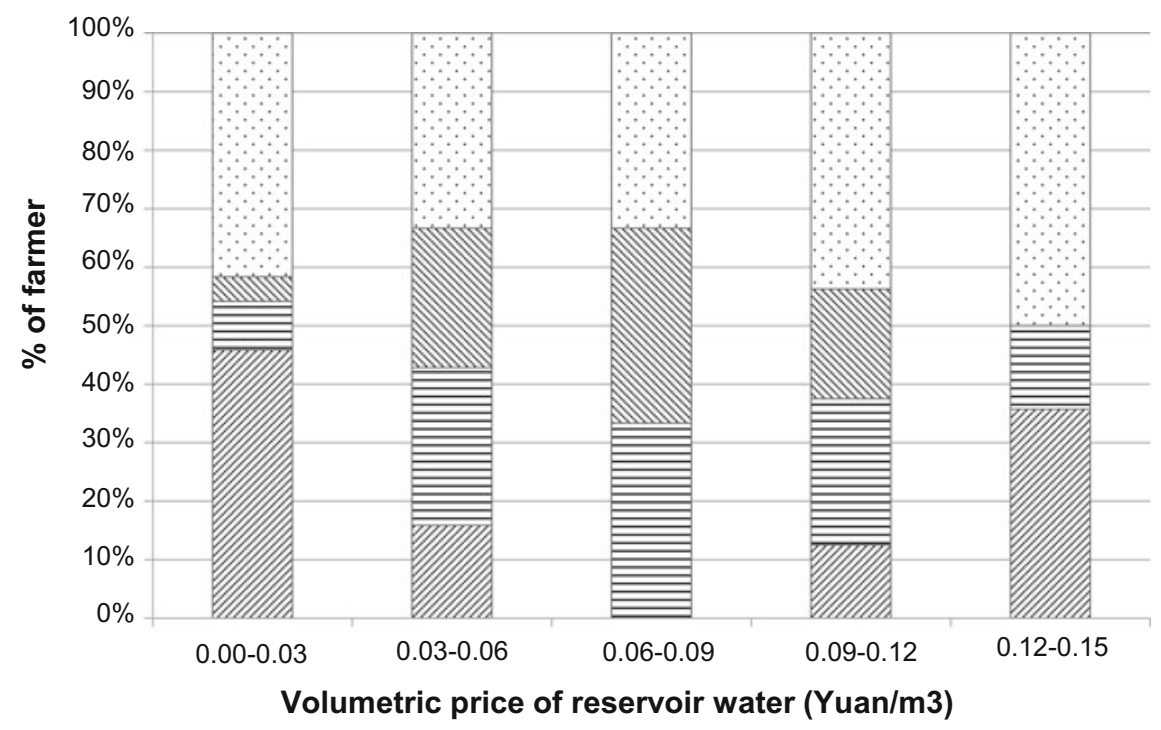

$\square$ No change/informal $\boxminus$ Manager appointment $\mathbb{N}$ New smaller group $\square$ Individual

Fig. 12.4 The proportion of sample farmers in the four types of irrigation institutions by the volumetric price of reservoir water, Zhanghe Irrigation System, Hubei, China in 2008. Source Kajisa and Dong (2017)

Table 12.1 presents the average water prices and water use of the sample farmers by water management institution. ${ }^{9}$ Note that as the no-change cases were observed either under area-based pricing or under volumetric pricing, we further divide these cases into two categories. The upper part of the table, which shows WUG-level average price, indicates that the no-change case under volumetric pricing has the highest average volumetric price of all (0.080), being consistent with the existence of this case in the 4th and 5th price categories in Fig. 12.4.

The lower part of the table shows three kinds of farm-level water use statistics: total water use $(\mathrm{mm})$ consisting of reservoir water use $(\mathrm{mm})$ and individual water use $(\mathrm{mm})$, where water use is measured in terms of the cumulative net water depth $(\mathrm{mm})$ applied to a paddy field of a farmer. Our major focus is on the change in reservoir water use with application of volumetric pricing. The table shows that farmers reduced reservoir water use in all institutions under volumetric pricing, as in the cases of (2), (3), and (4). However, it is worth noting that the farmers in the nochange case — the case of (2) — saved the least water (144 mm, significantly different from the area-based case, $232 \mathrm{~mm}$, at 10\%), in spite of the highest average volumetric price level. A more significant reduction is observed in the manager appointment case (102 mm, significant at 1\%) and the new smaller group case $(89 \mathrm{~mm}$, significant at

\footnotetext{
${ }^{9}$ Note that the non-price restriction on water use (e.g., a quota) did not exist in any pricing method. Hence, this restriction was not the reason for water savings.
} 
Table 12.1 Water price and water use by water institution of sample farmers, Zhanghe Irrigation System, Hubei, China in 2008

\begin{tabular}{|c|c|c|c|c|c|}
\hline & \multicolumn{5}{|l|}{ Institution } \\
\hline & $\begin{array}{l}\text { (1) } \\
\text { Area-based } \\
\text { no change }\end{array}$ & $\begin{array}{l}\text { (2) } \\
\text { Volumetric } \\
\text { no change }\end{array}$ & $\begin{array}{l}(3) \\
\text { Manager } \\
\text { appointment }\end{array}$ & $\begin{array}{l}\text { (4) } \\
\text { New smaller } \\
\text { group } \\
\text { formation }\end{array}$ & $\begin{array}{l}(5) \\
\text { Individual }\end{array}$ \\
\hline \multicolumn{6}{|l|}{ WUG-level variable } \\
\hline $\begin{array}{l}\text { Volumetric price of } \\
\text { reservoir water } \\
\left(\text { Yuan } / \mathrm{m}^{3}\right)\end{array}$ & & $\begin{array}{l}0.080 \\
(0.035)\end{array}$ & $\begin{array}{l}0.063 \\
(0.030)\end{array}$ & $\begin{array}{l}0.061 \\
(0.025)\end{array}$ & $\begin{array}{l}0.066 \\
(0.039)\end{array}$ \\
\hline $\begin{array}{l}\text { Area-based fixed } \\
\text { price of reservoir } \\
\text { water (Yuan/ha) }\end{array}$ & $\begin{array}{l}290.5 \\
(209.1)\end{array}$ & & & & $27.9(113.2)$ \\
\hline \multicolumn{6}{|l|}{ Farm-level variable } \\
\hline $\begin{array}{l}\text { Total water use } \\
(\mathrm{mm})\end{array}$ & $235(138)$ & $197(85)$ & $163 *(114)$ & $114 * * *(81)$ & $175(133)$ \\
\hline $\begin{array}{l}\text { Reservoir water use } \\
(\mathrm{mm})\end{array}$ & $232(140)$ & $144 *(80)$ & $102 * * *(82)$ & $89 * * *(66)$ & \\
\hline $\begin{array}{l}\text { Individual water use } \\
(\mathrm{mm})\end{array}$ & $3(9)$ & $54 * *(67)$ & $61 *(102)$ & $25(67)$ & $\begin{array}{l}175 * * * \\
(133)\end{array}$ \\
\hline No. of obs. (farmers) & 11 & 17 & 31 & 25 & 51 \\
\hline
\end{tabular}

Source Kajisa and Dong (2017)

Note Standard deviations are in parentheses. *Indicates $t$-test for the mean difference in water use from (1) Area-based no change, $* p<0.1, * * p<0.05$, *** $p<0.01$

$1 \%$ ). This narrative is quantitatively verified by means of regression analyses in Kajisa and Dong (2017).

Why did volumetric pricing not work as expected when the price was set very high? It should be noted that a high price induced the exit of surface gravity irrigation users and, additionally, that the surface gravity irrigation systems entail externalities. After the exit of some farmers in favor of private ponds, the remaining surface irrigation users' plots became separated by the pond users' plots and, thus, became segmented from each other, which made it difficult for a remaining surface water user to observe the other remaining users' water use. Moreover, the farmers who exited from surface irrigation were likely to put much less effort into (or even stop participating in) surface irrigation management. Hence, the exit of some members from the WUG made the management and maintenance by the remaining farmers too difficult to continue, resulting in the failure of water savings among them despite the very high water price. We note that our study area may be more likely than other areas to suffer this kind of problem because the topography of the area is rolling and thus it is difficult to observe other farmers' irrigation behavior unless they are immediate neighbors. Furthermore, an increasing popularity of non-agricultural work opportunities would further decrease incentive for strict management, having aggravated this problem. Hence, this example may be an exaggerated case and similar cases may not be easily 
found in other areas. Nevertheless, the basic logic may be applicable to other areas as one of the reasons for declining collective management. Indeed, this case is similar to Japan's experience during its rapid industrialization, in which the exit of full-time farmers resulted in the decline of collective management.

What are the lessons from China's case? It implies that volumetric pricing is an effective method for water savings but needs a careful implementation because water savings failed when strict management became difficult under labor shortage (due to exit to private ponds in this case). Based on Japan's experience, we suggest that the authority may support the substitution of capital for labor, so that the system can be managed properly with fewer users. A possible option is to support investments in canals and water control devices to make water flow more visible (and thus measurable) and controllable (ideally, the system should be something similar to a domestic water system). To enhance the effect of this investment, reshaping of paddy fields into a more regular shape would be effective. Currently, Chinese farmers own several small parcels over scattered areas. The creation of a few larger parcels through merging and exchanging with others also makes water management easier. This is indeed what Japan did in its rapid industrialization period. Another lesson from Japan is that China seems to already be in the stage of rising agricultural protection and now they may have to be cautious about over-investment in such facilities.

\subsubsection{The Case of Tank Irrigation Systems in Tamil Nadu, India $^{10}$}

Traditional irrigation systems in Tamil Nadu are tank systems, which consist of a water storage area (a tank), sluices, and canals. This communal infrastructure has collectively been managed by informal local bodies. Farmers use this irrigation water mainly for rice (the staple food of the area), as well as for cotton, groundnuts, sugarcane, and vegetables.

Three factors accelerated the exit of the farmers from tank systems during the early 1990s: (1) migration to urban and foreign non-agricultural sectors, (2) reductions in electric pump prices and well-digging costs, and (3) a free electricity power policy. The first factor, migration, started with the country's rapid industrialization when the government started its economic liberalization policies in 1991. In addition, globalization made overseas works more accessible. An important change underlying this trend was that water tenders, called Neerkatti in local terms, who were hired from some specific scheduled caste families under a hereditary system, left water management for non-agricultural work, seeking higher wages as well as freedom from the hereditary system (Jegadeesan and Fujita 2011). This is similar to what happened in Japan in that the scarcity of experienced water tenders increased with the rapid industrialization. The second and the third factors caused the massive diffusion of private wells and pumps (Fig. 12.5). The shift in the relative share in Fig. 12.5

\footnotetext{
${ }^{10}$ This section draws heavily on Kajisa (2012) and Kajisa et al. (2007).
} 


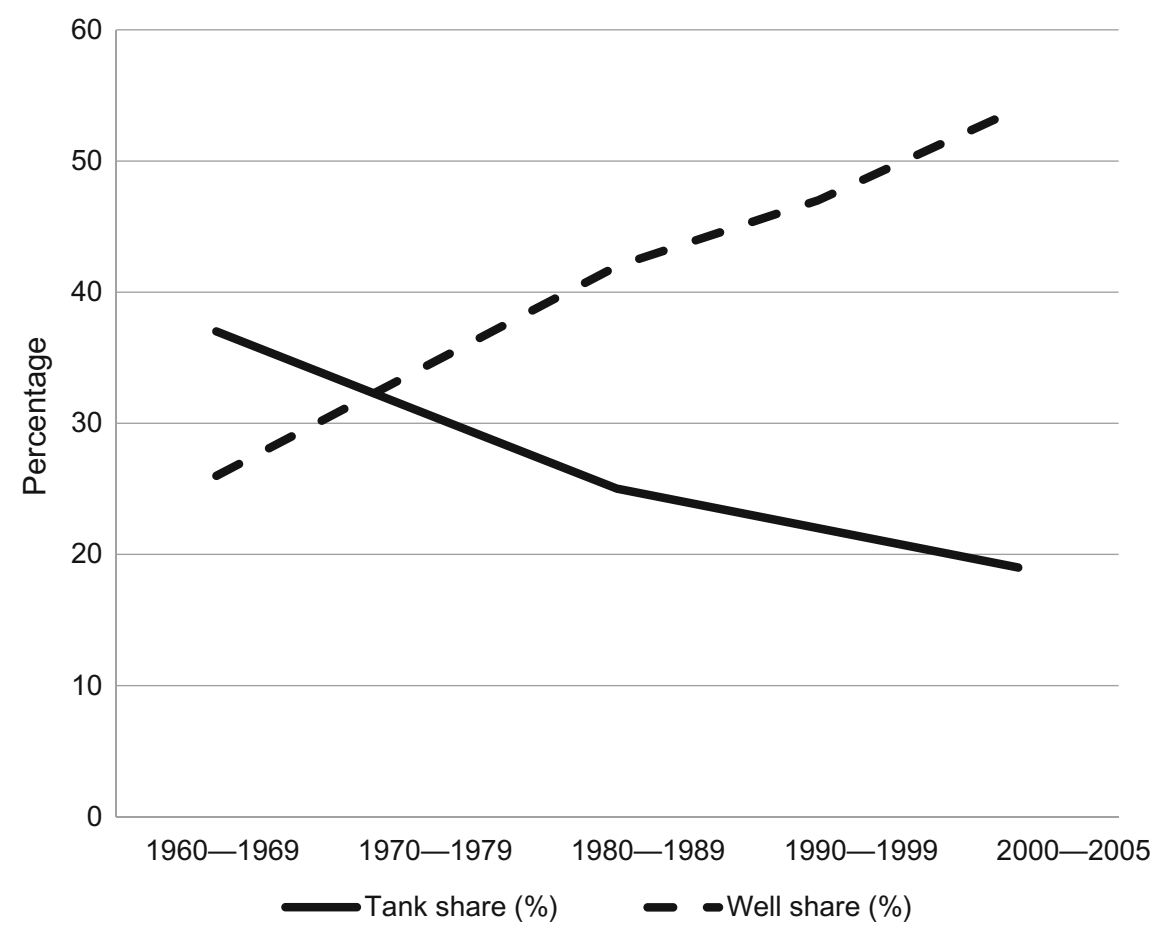

Fig. 12.5 Percentage share of well-irrigated and tank-irrigated area in total irrigated area in Tamil Nadu from 1960 to 2005. Source Kajisa et al. (2007)

reflects not only a preference for private wells when new systems were installed, but also the actual replacement of tank systems with well systems (Paramasivam 2009). This hastened the exit of farmers from the tank irrigation system.

The exit of such farmers eventually resulted in the decline of tank management, and hence agricultural performance in the tank irrigated area, because of the negative externality caused by their exit. Then, as a reaction to this change, more farmers tended to switch to pumps and wells for groundwater irrigation. As such, a vicious cycle can be observed. From the welfare point of view, the worst case was that farmers suffered from tank deterioration but had no recourse to groundwater. The rice yields greatly declined in this case. Table 12.2 summarizes the rice yield, household income per capita, head count poverty ratio, and rice profit by irrigation status, classified by the condition of tanks (deteriorated or maintained) and by the access to groundwater (access or no access). The aforementioned worst case corresponds to column (1) in the table. The table shows not only that this group achieved the lowest rice yield, but also that the compensation for yield loss through income diversification was difficult and, thus the farmers in this group obtained the lowest income and tended to fall into poverty. 
Table 12.2 Comparison of rice yield, income, poverty ratio, and rice profit by irrigation status of sample farmers, Tamil Nadu, India, in 1999

\begin{tabular}{l|l|l|l|l}
\hline Irrigation status & $(1)$ & $(2)$ & $(3)$ & $(4)$ \\
\hline Condition of tank & Deteriorated & Maintained & Deteriorated & Maintained \\
\hline Access to wells & No-access & No-access & Access & Access \\
\hline Rice yield (t/ha) & 3.2 & 3.6 & 4.4 & 4.1 \\
\hline $\begin{array}{l}\text { Household income per capita } \\
\text { (Rs./month) }^{\mathrm{a}}\end{array}$ & 262 & 309 & 561 & 589 \\
\hline Head count poverty ratio $^{\mathrm{b}}$ & 0.67 & 0.59 & 0.30 & 0.24 \\
\hline Rice profit (Rs./ha) & -929 & 4,801 & 1,897 & 5,619 \\
\hline
\end{tabular}

Source Kajisa (2012)

Note ${ }^{\text {a }}$ The value is converted into a per capita base using the adult equivalent number of household members

${ }^{\mathrm{b}}$ The international poverty line of US $\$ 1$ per day, adjusted for purchasing power parity, has been used. Use of the national poverty line of Rs. 324 (equivalent to US\$ 36.4 at PPP exchange rate) monthly per capita for 1993-94 does not change the qualitative results

The story does not end here; some negative effects were also experienced by well users. As groundwater extraction entails negative externality, as explained earlier, the likely outcome is the overexploitation of groundwater beyond a socially optimal level, and thus more costly irrigation. ${ }^{11}$ Eventually, well users became unable to earn as much profit for rice as they had previously due to the unsustainable depletion of the water resource. Table 12.2 shows that among the groundwater users (columns (3) and (4)), the profit obtained with deteriorated tanks is much lower than in the other case, regardless of the fact that they did not have to rely overly on deteriorated tanks. Provided that such tank deterioration occurred in high well density areas, the most likely reason for the lower profit was the costlier well irrigation due to groundwater scarcity in the high well density area. In fact, a major reason for lower profit is increased family labor costs for longer and more careful groundwater irrigation. Detailed regression analyses support this narrative (Kajisa 2012). In summary, the exit of farmers from tank irrigation to groundwater irrigation resulted in a double tragedy: increased poverty among tank users who had no recourse to groundwater and potentially no long-term profit among groundwater users. Currently, the implementation of generous social safety net polices, such as a work guarantee program and food rationing, have masked the complaints from the farmers, but the tragedy in agriculture has been actually taking place behind the mask.

What should the authority do? First, some policies discouraging investment in groundwater irrigation are needed. Such policies would not only reduce the overexploitation of groundwater but would also encourage the revitalization of tank irri-

\footnotetext{
${ }^{11}$ Under the free electricity policy in Tamil Nadu, an increase in irrigation costs largely derives from an increase in family labor input. When the groundwater table declines, farmers must spend a longer time working for the same amount of water and prepare field water channels with greater care to minimize water loss. Our observations indicate that the activities related to such operations are carried out mostly by family labor, rather than by hired labor, to avoid shirking and cheating.
} 
gation management (by increasing the number of farmers remaining in the tank system). The termination of the free electricity policy sounds reasonable and effective but could be politically difficult because politicians fear the loss of votes from rural farmers. As Japan's experience shows, an overdose of agricultural protection is one of the most challenging problems in the rapidly growing countries. We must focus our greatest efforts on finding solutions to this issue.

Second, similar to the cases of Japan and China, support for the substitution of capital for labor is another possible solution. ${ }^{12}$ This support is justifiable not only from the viewpoint of the existence of the first type of externality but also from that of second type because people started recognizing the amenity benefits of the tanks. ${ }^{13}$ Note, however, that concrete canal lining or pipeline installations, as in Japan, might not be the appropriate means of substitution because water flow and the location of water intake will be fixed once such facilities are installed. In Tamil Nadu, farmers cultivate multiple crops over the seasons in a single year, and they also change cropping patterns over the years. Hence, the water flow structure in the command area must remain flexible. A possible labor-saving intervention might be the use of heavy machines for tank cleaning to maintain the supply capacity. Such substitutions must proceed in a way that suits the local farming systems.

\subsection{Concluding Remarks}

In all three cases, the fundamental underlying change was the decline in the number of traditional irrigation system users. Therefore, the most appropriate strategy reflecting the change in factor endowment is the substitution of capital for labor. Neither the market nor the community can achieve this substitution properly because of the increasing externalities and the rapid decline of community mechanisms in the emerging states. We must understand that the demand for active involvement of the government increases for these countries and the government should not hesitate to implement policies supporting labor saving investments in irrigation management. ${ }^{14}$

It is important to recognize this point because we tend to assume abundant labor in rural area in LDCs and, thus, try to develop strategies for labor mobilization for

\footnotetext{
${ }^{12}$ The tanks larger than $100 \mathrm{ac}$. are already under the control of public authority (Public Works Department), meanwhile those smaller than 100 ac are under the control of local communities. Our implication applies particularly to the latter ones.

${ }^{13}$ Encroachments of residences in the water catchment area, which reduces the amount of water stored in the tanks, is a unique problem of tank irrigation system. This is another example of negative externality which require some interventions.

${ }^{14}$ Revitalization or restructuring of a community as a new unit with the new linkages among the members can be an alternative solution to the decline of the traditional community. Japan's experience, however, implies that seeking this solution is not easy because the support for group farming did not work successfully and then the government has eventually shifted toward an individual support. Nevertheless, we do not deny the potential role of the new community in the aspects other than irrigation management. One possible benefit may be the provision of informal social safety net among the newly linked members.
} 
successful collective management. With the academic success of Ostrom's group, the development society seems to believe the high potential of the community to achieve successful collective management. In fact, development strategies such as the community participatory approach and the transfer of management to local institutions boomed in the 1980s. The community seems to have been used as a convenient institution for solutions to resource management issues. However, the use of community is not a panacea, which is particularly so among emerging states. ${ }^{15}$ The government can also play an important role.

The role of government is more important among the emerging states because of two contemporary issues. First, the overexploitation of groundwater is a serious problem in many LDCs. Since this problem is related with negative externality, we can find again an important role of the government. Second, not only the groundwater but also fresh surface water is becoming scarce in the emerging states because of the increasing demand in industrial and urban sectors. Introduction of volumetric irrigation water pricing is regarded as one of the solutions for water savings in the agricultural sector. To make this system work in the emerging states, the modernization of irrigation facilities for water control and measurement must come together with the introduction of a new pricing system. This strengthens our argument on the necessity for smooth substitution of capital for labor. These two contemporary issues indicate that the emerging state must deal with resource scarcity issues more seriously than the time DCs used to do, and the role of the government is becoming crucially important.

Although we admit an increasing importance in the role of the government, we also learn from Japan's experience that we need some mechanism which helps us circumvent excessive support following the trend for increasing agricultural protectionism during rapid industrialization. The protection of the agricultural sector can have a positive role in the economic development under certain contexts. For example, it can reduce the risk of social unrest in rapidly growing economies where the agricultural income grows slower than that of the industrial sector. However, the support provided must be that which can achieve sustainable agricultural growth thorough the correction of externalities, rather than that which will result in stagnation under such protection.

In this regard, we cannot be too optimistic about the direction China and India are moving in. Anderson and Martin (2008) shows the increasing trend of the nominal rate of assistance, an indicator of agricultural protection, of these two countries. Although the level of protection was still low (6\% for China and 16\% for India in 2000-2004, compared with 137\% in Korea and 61\% in Taiwan), the trend shown in these countries is the same as the one predicted by Honma's political economy framework (see Chap. 10). Moreover, in India, the source of protection largely came from subsidies for fertilizer and electricity (for irrigation pumps), which are for farmers' income support but not for sustainable agricultural growth (Anderson and

\footnotetext{
${ }^{15}$ It is not Ostrom who advocated the versatileness of community. Rather, the development society seemed to overdose such policies. In later year, Ostrom (2007) and Meinzen-Dick (2007) tried to adjust the trend in their synthesis using a phrase of "beyond panaceas."
} 
Martin 2008). Our cases exemplify the difficulties the emerging states would face in circumventing the trap of agricultural protectionism. However, the government must clearly understand that maintaining the support and protection without productivity improvement eventually become a huge financial burden to the state. Choosing appropriate policies under pressures from different interest groups is a challenging political economy issue for the emerging states, but they certainly must deal with it by upgrading their political systems and convince their citizens not to repeat the same mistake that some DCs had made.

\section{References}

Anderson, K., \& Martin, W. (Eds.). (2008). Distortions to agricultural incentives in Asia. Washington, DC: World Bank.

Jegadeesan, M., \& Fujita, K. (2011). Deterioration of the informal tank institution in Tamil Nadu: Caste-based rural society and rapid economic development in India. Southeast Asian Studies, 49(1), 93-123.

Kajisa, K. (2012). The double tragedy of irrigation systems in Tamil Nadu, India: Assessment of the replacement of traditional systems by private wells. Water Policy, 14, 371-390.

Kajisa, K., \& Dong, B. (2017). The effect of volumetric pricing policy on farmers' water management institutions and their water use: The case of water user organization in an irrigation system in Hubei, China. World Bank Economic Review, 31(1), 220-240.

Kajisa, K., Palanisami, K., \& Sakurai, T. (2007). Effects on poverty and equity of the decline in the collective tank irrigation management in Tamil Nadu, India. Agricultural Economics, 36(3), 347-362.

Lohmar, B., Huang, Q., Lei, B., \& Gao, Z. (2007). Water pricing policies and recent reform in China: The conflict between conservation and other policy goals. In F. Molle \& J. Berkoff (Eds.), Irrigation water pricing: The gap between theory and practice. Oxford: CABI.

Meinzen-Dick, R. (2007). Beyond panaceas in water institutions. Proceedings of the National Academy of Science, 104(39), 15200-15205.

Ministry of Agriculture, Forestry and Fisheries. (Various Years). Nougyou syuokuryou kannren sangyou no keizai keisan (in Japanese) (Economic accounting of agricultural and food industries), Ministry of Agriculture, Forestry and Fisheries, Tokyo.

Ministry of Agriculture, Forestry and Fisheries. (Various Years). Statistics section of the homepage. Retrieved November 6, 2017 from http://www.maff.go.jp/j/tokei/index.html.

Nakajima, Y. (1998). Nougyou nouson seibi jigyou to hozyo seido (Agrarian Development Projects and Government Support Programs). In M. Okuno \& M. Honma (Eds.), Nougyou Mondai no Keizaibunseki (Economic analysis of agrarian issues) Tokyo: Nihon Keizai Shinbun sha.

National Research Institute of Agricultural Economics. (1967). Nihon Nougyou no Tyouki Toukeisyuи (I) (in Japanese) (Long-term statistics of Japan's Agriculture). National Research Institute of Agricultural Economics, Tokyo.

Olson, M. (1965). The logic of collective action. Cambridge: Harvard University Press.

Ostrom, E. (2007). A diagnostic approach for going beyond panaceas. Proceedings of the National Academy of Science, 104(39), 15181-15187.

Paramasivam, P. (2009). Changing sources and emerging issues in the irrigation sector of Tamil Nadu Agriculture. In M. Chandrasekaran, N. Ajjan, N. Kumar, \& D. Suresh, (Eds.), Agricultural development issues in Tamil Nadu: Proceedings of the symposium conducted in 17th annual conference of agricultural economics research association, November 19-21, 2009. Coimbatore: Tamil Nadu Agricultural University. 
Tamaki, A., \& Hatate, I. (1974). Fudo daichi to ningen no rekishi (Ecology: history of land and human). Tokyo: Heibonsya.

Tamaki, A., Hatate, I., \& Imamura, N. (1984). Suiri no Syakai Kouzou (Social structure of irrigation). Tokyo: University of Tokyo Press.

Open Access This chapter is licensed under the terms of the Creative Commons AttributionNonCommercial-NoDerivatives 4.0 International License (http://creativecommons.org/licenses/bync-nd/4.0/), which permits any noncommercial use, sharing, distribution and reproduction in any medium or format, as long as you give appropriate credit to the original author(s) and the source, provide a link to the Creative Commons licence and indicate if you modified the licensed material. You do not have permission under this licence to share adapted material derived from this chapter or parts of it.

The images or other third party material in this chapter are included in the chapter's Creative Commons licence, unless indicated otherwise in a credit line to the material. If material is not included in the chapter's Creative Commons licence and your intended use is not permitted by statutory regulation or exceeds the permitted use, you will need to obtain permission directly from the copyright holder.

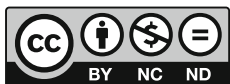

